Head of the Department of Criminal Law Research, Russian State University of Justice, Moscow, Russia Georgy Rusanov, Candidate of law (Russia),

PhD student at the University of Turin (Italy)

UDK: 343.71:930.85

UDK: 341.22:930.85

Рад примљен: 23.05.2017.

Рад прихваћен: 03.08.2017.

\title{
CRIMES AGAINST CULTURAL VALUES AS A BASIS OF INTERNATIONAL CRIMINAL RESPONSIBILITY
}

\begin{abstract}
The article discusses the problem of international criminal responsibility for crimes against cultural property. The authors consider three offenses against cultural values: smuggling of cultural values, destruction of cultural property, and theft of cultural property. The research of crimes against cultural values includes a number of issues: the nature of crimes against cultural values; the benefits of international or national character of responsibility for crimes against cultural values; the circumstances of commission of crimes against cultural property (e.g. the existence of an armed conflict); the objectives of the commission of crimes against cultural values (to export them as a treasure, to destroy the cultural heritage; to intimidate); the potential consequences of crimes against cultural values. On the basis of this program, the authors identify a number of models of crimes against cultural property. Each of these models is considered from the point of view of the possibility of international responsibility.
\end{abstract}

Keywords: crimes, cultural values, international law, smuggling.

*11081975@list.ru

georgyrusanov@mail.ru 


\section{Introduction}

The Cultural heritage is an important symbol of the existence of people and a state or civilization in general. Culture preserves the identity of a specific community of people. Without the existence of cultural heritage the link between generations is destroyed. Consequently, self-determination of the people is lost. Therefore, attacks on cultural values could potentially be used to destroy a specific ethnic or cultural community (Forrest, 2010).

Destruction of cultural heritage as a means of war has existed in the world since immemorial times (Jiri, 1999: 260-263). Suffice it to recall the shooting of the Great Sphinx in the Egyptian campaign of Napoleon. As a result, it was considerably damaged.

In recent years, a significant «contribution» in this direction was made by the ISIL (the Islamic State of Iraq and the Levant), which has embarked on a battle against the cultural heritage that is unacceptable to them. In particular, the following crimes against cultural property were committed by ISIL militants in 2015: the National Library of Mosul was detonated, as a result of which about 8 to 10 thousands of ancient books on culture, philosophy and history were destroyed; the tombs of the Shiite saint Muhammad binAli and Sufi religious leader Nizar Abu Baha al-Din were blown up; the Olympic Stadium in the Iraqi city of Ramadi was bombed (York, 2015: 22-23). According to the UNESCO data, about 10 thousand objects of cultural property are currently under the ISIL control. All of them are under the threat of destruction.

As a hypothesis of our research, we propose the following thesis: several crimes against cultural property have signs of international crimes according to the Statute of the ICC. Consequently, such crimes should be considered as international crimes.

\section{Research data and methods}

There is a system of crimes against cultural property in the laws of most states. This system includes several crimes: smuggling, destruction of cultural property, theft of cultural property. These three types of classic criminal offenses against cultural property will be considered by using a specific of research, which includes several important issues:

1) the nature of crimes against cultural values;

2) international or national character of responsibility for the crimes against cultural values; 
3) the circumstances of crimes against cultural property (e.g. the presence of an armed conflict);

4) the objectives of the commission of crimes against cultural values (to export them as a treasure, to destroy the cultural heritage; to intimidate);

5) the potential consequences of crimes against cultural values.

As the basis of research, we will use the analysis of judicial practice of the International Criminal Court, the analysis of the practice of the Russian courts on issues relating to crimes against cultural values, and the results of a survey of legal scholars specialized in matters of international criminal law and protection of cultural property.

\section{Results}

\subsection{Smuggling of cultural values}

The smuggling of cultural values is one of the most common crimes against cultural property (Pridanov, Sherba, 2002: 282).

At the moment, the International Convention on mutual administrative assistance for the prevention, investigation and repression of Customs offenses (Nairobi, 9 June 1977) is the main international instrument related to the fight against smuggling, regardless of its subject matter. According to art. 1 of the Convention, the term "smuggling" means fraud of the Customs consisting in movement of goods across a Customs frontier in any clandestine manner.

In 2015, the UN management representative on Drugs and Crime (J. Brandolino, 2015) noted that the smuggling of cultural property is a source of huge illegal profits. According to the UN statistics, the annual income of transnational criminal activities related to cultural values can range from 3.4 to 6.3 billion, i.e. $0.8 \%$ of all illicit financial flows.

As a rule, the nature of smuggling of cultural values is economic. The cultural property is moved across the border for the purpose of subsequent pecuniary interest, i.e. for sale. Yet, in recent years, the nature of smuggling cultural property has changed. So, during the «round table» held at the UNESCO headquarters in Paris in 2016, which was dedicated to the fight against trafficking in cultural property, it was noted that the conflicts in Iraq, Syria, Libya and Yemen directly contributed to a surge of illicit trade in archaeological objects. The income from such trafficking is used to finance terrorism. Therefore, once a purely economic crime, the purpose of which was to obtain illegal income, smuggling of cultural property has become a crime related to a complex array of actions aimed at the commission of a socially dangerous acts (e.g. terrorism). 
In modern jurisprudence, the issue of national or international jurisdiction concerning the_criminal liability for smuggling cultural values is usually resolved in favor of the national law. As a rule, a state of export of cultural values has the pre-emptive right to punish.

Our study of the Russian judicial practice has shown that the export of cultural values outside the Russian Federation was recorded in 95\% of cases of criminal liability for smuggling. This is largely due to the fact that the state (Russia is not an exception) is interested in the preservation of its cultural heritage. Consequently, the state is mainly trying to fight against the export of cultural property.

Meanwhile, smuggling is a displacement of an object from one country to another. Thus, there are two interested countries.The moving of cultural heritage within the administrative territory is not smuggling. The international character of this crime is determined by its essence.

The circumstances of committing an act of smuggling are an important factor, reflecting the social danger of smuggling cultural property. Above all, it refers to the presence of an armed conflict. During an armed conflict, the parties in conflict often illegally transfer cultural values to their territory. The typical example is the Second World War. For example, it is well known that a huge number of cultural values was illegally moved from the USSR to Germany; the search of famous Amber Room is still underway. It causes significant damage to the country of origin. According to a special protocol to the Convention on the Protection of Cultural Property in the Event of an Armed Conflict, each High Contracting Party undertakes an obligation to prevent the exportation of cultural property from an occupied territory during an armed conflict, as it is defined in Article I of the Convention for the Protection of Cultural Property in the Event of an Armed Conflict, signed at the Hague on 14 May, 1954. Thus far, the Protocol has been ratified by 87 states (the Convention was ratified by more than 100 countries). According to Article 11 of the Convention on the Means of Prohibiting and Preventing the Illicit Import, Export and Transfer of Ownership of Cultural Property, the export and transfer of ownership of cultural property under compulsion arising directly or indirectly from the occupation of a country by a foreign power shall be regarded as illicit. Thus, the international law prohibits the export of cultural property from an occupied territory during an armed conflict. Such a prohibition envisaged in the international law can potentially be the basis for international responsibility.

Notably, under this Convention, the import, export or transfer of the ownership of cultural properties effected contrary to the provisions adopted under this Convention by the States Parties will be illicit. Therefore, the ban extends not 
only to cases of international conflicts. The aim of the criminal act is another factor that should be taken into account when determining the nature of criminal responsibility for the smuggling of cultural property. The economic benefit is the main purpose of smuggling cultural property. Our expert survey and the analysis of the practice of the Russian courts showed that smuggling of cultural values had economic reasons in $90 \%$ of cases. Other cases are usually linked to the export of cultural property belonging to the defendant. But, the movement of such values across the border is restricted or prohibited.

The smuggling of cultural values in armed conflict zones is generally associated with the desire to obtain material resources. Cultural values are perceived as trophies and means of material enrichment. For example, according to the UN, one of the ISIL financial sources is the trafficking of cultural goods, including trafficking on the territory of European countries.

To sum up, it should be noted that there are two models of smuggling of cultural values:

A) The smuggling of cultural values committed for purely economic reasons. The subject matter of such smuggling is the cultural property acquired legally or illegally (according to interviews with experts, this model is found in about 95\% of all cases of smuggling of cultural values).

B) The smuggling of cultural values illegally acquired in the armed conflict zone. The purpose of such smuggling is basically economic interest but the income derived from the sale of cultural values can be used to fund future terrorist acts (according to the survey of experts, this model of smuggling of cultural values occurs in about $5 \%$ of all cases of smuggling of cultural values).

\subsection{Destruction of cultural values}

The destruction of cultural property is also one of the most common offenses against cultural property. The UNESCO periodically provides information on systematic actions aimed at the destruction of cultural heritage. For example, in 2013, the UNESCO was informed about the looting of the national museum of Malawi in El-Minya in Upper Egypt and the destruction of several religious monuments, including churches and mosques in Upper Egypt, El Fayoum and Cairo. In 2015-2016, many cultural artifacts were destroyed in Syria and other countries of the East (York, 2015: 22). At the same time, in judicial practice, there are cases involving the destruction of cultural heritage by individuals. For example, in 1975, the Rembrandt's painting "Night Watch" was cut by an unemployed teacher Wilhelm von Rajk. In 1985, Rembrandt's "Danae" in the 
Hermitage was spilled with acid, and then cut. The listing of similar examples involving the destruction of cultural values can be continued.

The UNESCO Declaration adopted in 2003, concerning the Intentional Destruction of Cultural Heritage states that a State which intentionally destroys or intentionally fails to take appropriate measures to prohibit, prevent, stop, and punish any intentional destruction of cultural heritage of great importance for humanity, whether it is inscribed or not in the list maintained by UNESCO or another international organization, bears the responsibility for such destruction to the extent provided for by the international law. States should take all appropriate measures in accordance with the international law, to establish jurisdiction over and provide effective criminal sanctions against those persons, who commit or order to commit acts of intentional destruction of cultural heritage of great importance for humanity, whether it is inscribed or not in the list maintained by UNESCO or another international organization.

Considering the nature of the destruction of cultural property, it should be noted that it is usually related to two aspects: personal and political. In this case, the nature of the destruction of cultural property is largely determined by the purpose of the act. The following purposes of destruction of cultural values should be noted:

a) Intimidation of population. The cultural heritage is destroyed by one of the belligerents in order to realize its military goals. In particular, it was the tactics of Nazi Germany during the Second World War. In recent years, cultural values are destroyed by the ISIL. Speaking on the deliberate destruction of Syria's precious heritage (in particular the archaeological sites of Palmyra and the Old City of Aleppo), Libya, Yemen and Iraq, the UNESCO Director-General said: «The intentional destruction of cultural heritage is a military crime, used as a tactic of war, designed to spread fear and hatred. The target of violentextremists is the culture, as they are well aware that their actions weaken the social structure and have a perniciouseffect on the ability of the population to resist».

A similar statement was made by the UNESCO Director-General on the situation in Iraq. She condemned the destruction of the ancient city of Nimrud in Iraq. She urged the international community to speak in one voice in defense of Iraq's cultural heritage. Irina Bokova has called the incident as a «criminal folly» and a war crime. The Head of UNESCO reported on the appeal to the International Criminal Court and the UN Security Council.

b) Political and ideological protest. Cultural values are a good target to attract attention in order to express one's political dissent. For example, it was exactly the cause of destruction of Rembrandt's «Danae» in the Hermitage. Persons who ostentatiously destroy cultural sites of avant-garde, modernist and post- 
modernist persuasion under the guise of protecting traditional religious values (and viceversa) have similar motivations.

c) Deprivation of a group's particular national, ethnic, linguistic, religious and cultural identity. As many national traditions are transmitted through culture and art, the widespread destruction of cultural heritage may be one of the steps aimed at the oppression of a particular national, ethnic, linguistic or religious group.

d) Destruction of economic potential. Culture has a serious economic potential. Many countries base their economy on tourism, associated with visiting cultural heritage sites. Hence, destruction of cultural objects can cause substantial damage to the country's economic potential.

The issue of international or national character of responsibility for the destruction of cultural property is of great importance. At present, the majority of national criminal laws establish liability for the destruction of cultural property. In international criminal law, the responsibility for crimes against cultural property is considered, as a rule, in the context of war crimes. Thus, according to Art. 3 of the ICTY Statute, seizure, destruction or willful damage done to the institutions dedicated to religion, charity and education, the arts and sciences, historical monuments and works of art and science are considered as a violation of the laws or customs of war.

A similar rule is contained in the ICC Statute. According to this act, intentional attacks against buildings dedicated to religion, education, art, science or charitable purposes, historical monuments, hospitals and places where the sick and wounded are situated, provided they are not military objectives, are considered the war crime. The elements of this crime are:

a) The perpetrator struck a blow.

b) The object of the attack was one or more buildings dedicated to religion, education, art, science or charitable purposes, historic monuments, hospitals or places where the sick and wounded are collected, which were not military objectives.

c) The perpetrator deliberately chose as the object of the attack such building or buildings dedicated to religion, education, art, science or charitable purposes, historical monuments, hospitals or places where the sick and wounded are situated, which were not military objectives.

d) The conduct took place in the context of an armed conflict not of international character and was associated with it.

e) The perpetrator was aware of factual circumstances that testified to the existence of an armed conflict. 
Currently, international liability for the destruction of cultural values is highly limited:

a) The List of items related to cultural values is restricted. Based on the elements of the crime, the international responsibility can take place only for attacks on buildings dedicated to religion, education, art, science or charitable purposes and historicalmonuments. At the same time, certain cultural values or their collections are not included into this list.

b) The presence of a military conflict is a mandatory circumstance of the destruction of cultural property. Therefore, it is necessary to consider this circumstance in detail. In the present judicial practice, it is assumed that the nature of conflict has no significance, i.e. it may be international or non-international. Thus, Jokic (case The Prosecutor vs Jokic M., IT-01-42-1) and Strugar were convicted for the destruction of cultural property under Article 3 (d) of the Charter. Concurrently, the nature of conflict was not clear. According to the ruling, Article 3 can be applied in both cases. The destruction of cultural heritage is raised to the level of international crime in the following cases:

(A) The act has led to the destruction of values that constitute the cultural or sacred heritage of the people;

(B) The destroyed property was not used for military purposes at the time of hostilities;

(C) The act was carried out with the aim to destroy these values.

Thus, the nature of the conflict is irrelevant for recognizing the act as an international crime. Cultural values are destroyed on a large scale, not only in times of an armed conflict. For example, the act may be aimed at oppressing a particular social, ethnic, religious, racial or linguistic group. Such a situation is possible, for example, in the form of destruction of books published in a rare language, spoken by a certain group of people, in order to destroy the cultural and linguistic identity of the group. A well-known historical example of burning of books is the destruction of more than 1.2 million books in Chisinau and more than 250 thousand books in Tiraspol, which happened in 1941 in the period of policy of Romanization after the Romanian troops occupied Bessarabia. All the books written in non-Romanian languages were destroyed.

The question of possibility of the international criminal responsibility for the destruction of cultural heritage is of great importance for determining the extent of the destruction of cultural property. Of course, in most cases it is impossible to speak about international liability for destruction of any individual objects, except when the object is so special and important for a state or nation that its destruction causes irreparable harm. 
Therefore, typical model actions in case of destruction of cultural property are as follows:

a) Destruction of one or more objects of cultural heritage by an individual;

b) Organized destruction of certain cultural values during an armed conflict;

c) Organized destruction of certain cultural values without an armed conflict;

d) Organized massive destruction of cultural values during an armed conflict;

e) Organized massive destruction of cultural values without an armed conflict.

In our opinion, in case of large-scale destruction of objects of cultural heritage, the destruction complies with the criteria of international crimes according to the ICC Statute, such as: "the seriousness of the offense" and "the concern of the international community."

\subsection{Theft of cultural property}

Theft of cultural property is one of the most common crimes in the world today. To a large extent, this type of crime is due to economic reasons because of the high cost of items of cultural heritage (Kuligin, 2002: 31-33). There are many well known examples of theft of certain cultural values. For example, the world's most famous painting "Mona Lisa" by Leonardo da Vinci was stolen in 1911; Rembrandt's self-portrait was stolen from the National Museum in Stockholm, Sweden, in 2000. The list could be continued. In particular, large-scale theft of cultural property took place during the Second World War. Until now, numerous international commissions have been trying to resolve the issues of return of cultural property to their rightful owners.

By its nature, the theft of cultural property is an economic crime. The perpetrator of this crime usually steals cultural values in order to obtain economic benefits. The beneficiaries may be individuals on whose behalf the theft was committed, as well as the states which obtain cultural properties as war trophies. It should be noted that the theft of cultural property, as a rule, is directly related with the previously discussed smuggling of cultural values. These crimes often have a single chain of events: a cultural property is stolen and exported to the territory of another country (Fomichev, 2005: 180-181).

A theft of cultural property, as a rule, is a crime according to the national criminal law. Almost every state sets its own legal protection of cultural heritage from criminal attacks. In most cases, it does not matter whether properties belong to the state or private citizens. The nature of liability for the theft of cultural 
property is a question of circumstances of the crime. As in other crimes against cultural property, the first one is the presence of an armed conflict.

During an armed conflict, there is theft of cultural property organized by the state and theft of cultural property committed by individuals directly involved in armed conflicts (individuals officially serving in the armed forces of one of the parties involved in the conflict). Also, theft of cultural property can be committed by individuals who are not direct parties to the conflict (the so-called marauding). It should be noted that the percentage of stolen cultural properties during an armed conflict is not more than $10-15 \%$ of the total number of stolen cultural properties ( $70 \%$ of the surveyed experts called this percentage).

The question of the scale of such thefts is of great importance for consideration and classifying specific cases of thefts of cultural property as international crimes. Most thefts of cultural property imply a theft of one or more cultural values. Concurrently, there have been cases of large-scale thefts in history (e.g. previously noted cases during the Second World War). It should be noted that a large-scale theft may be associated with a single object which has a special historical or cultural importance, such as the Amber Room which was stolen by Nazi Germany and exported from the USSR during the Second World War.

In general, there are the following typical models of thefts of cultural values:

a) theft of one or more objects by individuals in their own interests in times of peace;

b) theft of one or more cultural values by individuals during an armed conflict (either as direct participants of an armed conflict or not);

c) large-scale organized theft of cultural properties under the auspices of the State during an armed conflict.

\section{Discussion}

In this part of our research, we will consider the possibility of recognizing typical models of actions related to the commission of offenses against cultural properties as international crime.

1. Smuggling of cultural values acquired by legal or illegal means for economic reasons only. Such model can be organized and unorganized. Thus, smuggling can be committed by individuals and by organized criminal groups, specializing in smuggling cultural values. However, such an act cannot satisfy the criteria of an international crime: "the seriousness of the offense" and "the concern of the international community." As a rule, such cases do not have large-scale consequences. Therefore, the perpetrator should be prosecuted in accordance 
with the national criminal law (this approach is supported by $100 \%$ of the surveyed experts).

Despite the lack of international responsibility, this model of smuggling cultural values has an international character. Smuggling cultural values always requires moving an object across the border. Consequently, the cooperation of States in combating this crime and return of cultural values is essential.

2. Smuggling of cultural values acquired in the armed conflict zone. This issue is much more complicated and controversial, and should be considered from two aspects: a) organized smuggling of cultural values under the auspices of the state on the occupied territory; and b) smuggling committed by individuals during an armed conflict.

Organized smuggling of cultural values during an armed conflict suggests a sequence of actions to implement the intention of the State party in the conflict to export cultural values to the territory of another state. This is the most dangerous form of smuggling of cultural values, implying large-scale activities of the state.

In this regard, the issue of compliance of such offence with the criteria of an international crime should be considered. The most comprehensive account of such criteria was set out in the Statute of the ICC: "the seriousness of the offense" and "the concern of the international community". Despite the fact that the criteria are evaluative, we believe that a large-scale smuggling of cultural values from one country to another during an international conflict will certainly cause significant harm to the victim and the State which violates the basic norms of human behavior. A particular problem is the case when the official authorities approve such activity, which should be the matter of concern of the international community. Our expert survey showed that $85 \%$ of respondents believe that a large-scale smuggling of cultural property committed during an armed conflict must be considered as an international crime. At the same time, $60 \%$ of the surveyed experts believe that such liability is possible only in case of an international conflict, while $40 \%$ of experts believe that such responsibility should be applied in case of both international and internal conflicts. It seems that the nature of conflict is essential for this kind of smuggling. Displacement of cultural heritage within the administrative territory has no signs of smuggling because there is no movement of the object across the border. Consequently, it cannot be considered an international crime. The classification into a specific type of international crime is a debatable issue when it comes to a large-scale smuggling of cultural property during an armed conflict. It seems that specific circumstances of commission of the crime indicate that such an act must be considered as a war crime. 
The second aspect of the issue is related to cases where the smuggling of cultural values during an armed conflict was committed by individuals. As a rule, such actions during armed conflicts occur either for economic reasons (easy extraction of money) or for any personal reasons (desire to collect memories). There are two situations: the crime is committed by a person who is a participant of the conflict (combatant), and the crime is committed by a person who is not a participant of an armed conflict (noncombatant). We believe that both variants of action do not contain the features of international crime because they have no serious effects typical for such acts (this approach is supported by $98 \%$ of the surveyed experts). However, smuggling of cultural values committed during an armed conflict is an increased public danger. Consequently, the commission of such acts should entail more strict punishment, but according to the rules of the national criminal law.

3. Destruction of one or more of the objects of cultural heritage by an individual is committed for personal reasons. Such actions cannot have a large-scale character although the cost of the destroyed object can be quite large. Nevertheless, such an act does not correspond to features of international crime, both in terms of the seriousness of the offense and the concerns of the world community. In this case, the perpetrator may be subject to criminal liability under the rules of the national criminal law; notably, $100 \%$ of surveyed experts supported the approach that the destruction of one or more objects of cultural heritage by an individual shall not be subject to international criminal liability.

4. Organized destruction of certain cultural values during an armed conflict. As a rule, this type of destruction of certain cultural values has political and ideological reasons. For example, the destruction of important historical, religious or cultural symbols of the enemy provides a psychological advantage or spreads fear. Great and important objects are usually chosen in such cases. International responsibility for the destruction of such objects is set in contrast to a number of other attacks on cultural values. Under the ICC Statute, international responsibility may occur only for attacks on buildings dedicated to religion, education, art, science, charity and historic monuments. Thus, it is recognized that this act corresponds to the features of international crime. Notably, $92 \%$ of surveyed experts supported the idea that the organized destruction of certain cultural values during an armed conflict is an international crime.

The question of considering this act as one of the forms of international crime is not relevant due to the fact that the international liability for the commission of this act is set in a number of international instruments, which have recognized that such a crime is a military crime. 
5. Organized destruction of certain cultural values without an armed conflict. This model is quite rare but possible. For example, it is possible when, inside a particular state, a national, racial or religious group destroys some important cultural property belonging to another group. This may occur to intimidate a group and to terminate cultural traditions, as well as to destroy the cultural identity of the group. Such organized actions are especially dangerous because they are part of the policy pursued by the state authorities. The current international criminal law does not establish liability for the commission of such acts. However, in our opinion, the organized destruction of certain cultural values without an armed conflict, but aimed at intimidation of a particular social community or elimination of the cultural identity of the group, corresponds to the features of an international crime specified in the ICC Statute. Such actions should be part of the policy aimed at oppressing of a specific group of people. Cultural values have special cultural and historical significance to a particular community of people (ethnic, linguistic, racial or religious group). The need to establish international liability for this crime was supported by $75 \%$ of the surveyed experts.

The question of classifying this crime into a specific type of type international crime is more complicated. We believe that crimes against humanity are the most appropriate type of the criminal acts for the organized destruction of certain cultural values without an armed conflict. We consider this issue in the light of features of crimes against humanity under the ICC Statute. According to Article 7 of the ICC Statute, «crime against humanity» means any of the following acts when committed as a part of a widespread or systematic attack directed against any civilian population, accomplished deliberately. Thus, a widespread or systematic attack against any civilian population is a mandatory feature of crimes against humanity.

According to the ICC Statute, "an attack directed against any civilian population" means a course of conduct involving the multiple commission of acts referred to in paragraph 1 against any civilian population, pursuant to or in furtherance of a State or organizational policy to commit such an attack.

Therefore, the first important aspect is whether we can consider the destruction of cultural property as a kind of an attack on the civilian population. The ICC Statute lists mainly physical acts: murder, rape, torture, etc. However, in our view, the destruction of cultural heritage is a form of psychological violence against a certain group of people. Therefore, it can be considered as a form of an attack on civilians. It should be noted that $65 \%$ of the surveyed experts agreed that the large-scale destruction of cultural heritage should be considered as an attack on civilians. "Widespread" and "systematic" attacks are two features of crimes against humanity. In theory, the international criminal law, as a rule, relates 
"widespread attacks" to the number of victims of attacks (Cryer, 2007:195). It should be noted that the practice of the International Criminal Court extends this approach. Large-scale attacks are associated not only with the number of victims of abuse but also with the width of the area of attacks. In particular, in the matter of The Prosecutor v. Omar Hassan Ahmad Al Bashir, the Court pointed out that the attack on the part of the civilian population of Darfur was widespread in nature because it was directed against at least hundreds of thousands of people and was carried out over large areas of Darfur region (Case: The Prosecutor v. OmarHassanAhmadAlBashir, ICC-02/05-01/09). In case of destruction of certain cultural values, the extent can be related to the number of potential victims of such acts, i.e. the number of persons for whom the destroyed items were of particular cultural value.

There are several approaches to the feature "systematic" for crimes against humanity.

According to some researchers, "systematic" means carefully organized activities related to the conduct of a common policy related to crimes against humanity with the participation of public resources. An example is the case of The Prosecutor v. Abdel RaheemMuhhamad Hussein. It was pointed out that there are reasonable grounds to believe that the attacks perpetrated by the Sudanese Armed Forces and/or the formation of militia "Janjaweed" were made in the context of a systematic and large-scale campaign. The campaign was based on public policy, which included attacks against the civilian population, mostly belonging to the Fur, Masalit and Zaghawa. These peoples were considered as the supporters of the rebels (Case: The Prosecutor v. AbdelRaheemMuhhamadHussein, ICC-02/05-01/12-2).

According to another point of view, the "systematic" character means planning of the commission of such acts by the supreme bodies of the state power, the scale and the continuity of crimes, the use of significant resources (Cryer, 2007:195).

There is another specific position in the case The Prosecutor v. Omar Hassan Ahmad Al Bashir. It was stated that acts of violence were systematic because they followed largely the same schema (Case: The Prosecutor v. OmarHassanAh madAlBashir,ICC-02/05-01/09).

In our opinion, the sign of the systematic destruction of certain cultural values is an organized and deliberate character of such actions on the part of the supreme bodies of the state power. At the same time, such destruction must be part of the common policy aimed at the suppression of a particular community. 
6. Organized massive destruction of cultural values without an armed conflict. Some signs of this crime are overlapping with the previously considered one, in particular, "attacks directed against any civilian population".

The necessity of envisaging the international responsibility for the crime was supported by $82 \%$ of surveyed experts. In our opinion, the offense such as the previous one should be considered as a crime against humanity. A widespread destruction of cultural values in this case can be characterized both by the number of potential victims of the crime and by the number of destroyed cultural values. The systematic character of destruction of cultural values in this case can also be expressed in the organized nature of such offences on the part of higher authorities and the frequency of such acts.

7. Organized massive destruction of cultural values during an armed conflict. The signs of this model are very similar to the signs of destruction of certain cultural values during an armed conflict. Nevertheless, there is a significant feature associated with the fact that the international responsibility does not work every time for such an act. For example, the destruction of the library containing a large number of books is a military crime under the ICC Statute. However, the destruction of objects of cultural heritage (for example, a large number of books) is not a war crime under the ICC Statute. This approach seems to be illogical. In our view, organized offences during an armed conflict, sanctioned by a state and aimed at the destruction of certain cultural values, comprise the features of an international crime (the seriousness of the offense, the concern of the international community). Consequently, a massive destruction of cultural property during an international armed conflict must be treated as a war crime. A total of $78 \%$ of surveyed experts supported this approach.

8. Theft of cultural property is a theft of one or more objects by individuals in their own interests in peacetime. This model is common. Such an act does not correspond to the features of an international crime listed in the ICC Statute. Even the theft of the most valuable cultural property unconnected with an organized policy of any state cannot have serious consequences for the world community. Consequently, such an offence should be punished only by the rules of the national criminal law. A total of $100 \%$ of surveyed experts supported this thesis.

9. Theft of one or more cultural values by individuals during an armed conflict. This model is more complex in terms of assessing the possibility of international responsibility. In this case, it is necessary to consider two possible developments. The first case is related to the theft of objects by individuals. Such cases are common during an international conflict and, in most cases, civilians are the victims of these actions. It seems that this should be considered as a military crime. However, the offences of individuals that violated the international law 
without the general policy of the State must not be considered as international crimes. This is due to the fact that such actions of individuals cannot contain signs of an international crime. In this case, liability is possible only under the national criminal law. It should be noted that $95 \%$ of polled experts supported this thesis.The issue of a theft of certain cultural values within a unified policy of the state is solved differently, for example, when there is a specific purpose to steal the cultural values belonging to other participants of the conflict.These organized actions supported by the leadership of a state in the event of significant damage as a result of the theft should be considered as an international crime. The situation of an armed conflict suggests that such an offense is a military crime. A total of $68 \%$ of polled experts supported this approach.

10. Large-scale organized theft of the cultural property under the auspices of the State during an armed conflict. There are two aspects of this model: when the authorities give the order to plunder a particular area, and when they try to find objects of cultural heritage for the purpose of their subsequent exportation. In both cases, it seems that the patronage of the state makes such actions an international military crime. Such actions may cause great damage because of a large-scale nature of the offence. At the same time, the scale of such acts is difficult to control. A total of $85 \%$ of surveyed experts supported the view that a large-scale organized theft of the cultural property under the auspices of the State during an armed conflict should be regarded as an international crime.

\section{Conclusions}

Summarizing the investigation of various models of attacks on cultural values, a number of theses should be allocated:

1. International responsibility for attacks on the cultural property at present is selective and covers only some possible models of crimes against cultural heritage. International responsibility for crimes against cultural property should be expanded by including a series of acts.

2. The following models of attacks on cultural values should be considered as international war crimes:

a) Large-scale smuggling of cultural property committed during an international armed conflict;

b) Organized (under the patronage of the state) destruction of certain cultural property during an armed conflict;

c) Theft of one or more cultural values by individuals during an armed conflict as part of common policy of a State. 
d) Large-scale organized theft of cultural property under the auspices of the State during an armed conflict.

3. The following models of attacks on cultural values should be considered as crimes against humanity:

a) Organized (under the patronage of a state) destruction of certain cultural values of particular historical, cultural and religious significance to a particular group of persons without an armed conflict in order to intimidate a certain community of people, differing on national, racial, social or linguistic grounds.

b) Organized (under the patronage of a state), large-scale destruction of cultural values without an armed conflict to intimidate a certain community of people, differing on national, racial, social or linguistic grounds.

\section{References}

Kuligin ,V. (2002). Criminal law protection of cultural values. Khabarovsk, 2002. [Кулыгин В. В. Уголовно-правовая охрана культурных ценностей. Хабаровск. 2002].

Pridanov, S., Sherba S. (2002). Crimes against culture values. Moscow, 2002. [Приданов С. А., Щерба С. П. Преступления, посягающие на культурные ценности: квалификация и расследование. Москва, 2002].

Cryer, Robert; Hakan Friman, Darryl Robinson, Elizabeth Wilmshurts (2007). International criminal law and procedure. Cambridge University Press, 2007.

Fomichev, S. (2005) Smuggling of cultural values: dis....cand of law. Ulyanovsk, 2005. [Фомичев С. А. Контрабанда культурных ценностей: Дис....канд. юрид. наук. Ульяновск, 2005].

Forrest C. (2010). International law and the Protection of cultural values. LondonNew-York, 2010.

Jiri, T. (2009). Cultural property in war: improvement in protection. Paris, 2009.

York, R. (2015). Know thy Enemy. Islamic State of Iraq and the Levant.London, 2015.

Case: The Prosecutor v. OmarHassanAhmadAlBashir // ICC-02/05-01/09-1.

Case: TheProsecutor v. AbdelRaheemMuhhamadHussein // ICC-02/05-01/12-2.

Case: The Prosecutor v. Jokic M. // IT-01-42-1 
Профб. Јури Пудовочкин, доктор правних наука, Управник катедре за кривичноправна истраживања, Руски државни Универзитет правде, Москва, Русија Георги Русанов, Кандидат за доктора правних наука (Русија), Докторанд Универзитета у Торину (Италија)

\section{КРИВИЧНА ДЕЛА ПРОТИВ КУЛТУРНИХ ДОБАРА КАО ОСНОВ КРИВИЧНЕ ОДГОВОРНОСТИ У МЕЪУНАРОДНОМ ПРАВУ}

\section{Сажетак}

Чланак се бави питањем међународне кривичне одговорности за кривична дела против културних добара. Аутори анализирају кривична дела против културних добара: кријумчарење културних добара, уништавање културних добара и крађа културних добара. Истраживање кривичних дела против културних добара обухвата низ питања: природа кривичних дела против културних добара; користи од међународног или националног карактера одговорности за кривична дела против културних добара; околности вршења кривична дела против културних добара (нпр. постојање оружаног сукоба); циљеви вршења кривичних дела против културних вриједности (да се извозе као благо, уништи културно наслијеђе, застраши); могуће последище привичних дела против културних добара. На основу тога, аутори идентификују низ модела кривичних дела против културних добара. Сваки од ових модела се посматра са становишта могуће кривичне одговорности умеђународном праву.

Кључне речи: кривична дела, културна добра, међународно право, кријумчарење. 